\title{
LOS CONJUROS Y OTROS MICROCUENTOS DE CARLOS ENRIQUE CABRERA
}

\section{Fernando Valerio-Holguín Colorado State University}

Profesor del Instituto Tecnológico de Santo Domingo (INTEC) y director de la revista Caudal, Carlos Enrique Cabrera ha publicado los siguientes libros:

Reflexiones de bolsillo (2002), Español universitario (2006), Tiempos difíciles: ensayos sociales, culturales y filosóficos (2010) y Ciudad colonial Santo Domingo (2012). Su más reciente libro, Conjuros y otros microcuentos (2013), es un compendio de cincuenta y cinco microrrelatos. Deudor del boom latinoamericano, particularmente de los escritores Jorge Luis Borges y Cortázar, Carlos Cabrera resemantiza los espejos, el doble, el absurdo, los sueños y los espacios alternativos. Muchos de estos minitextos encuentran su articulación alrededor de antítesis y binarismos: vida/muerte, fantasia/realidad, sueño/ vigilia, vida/arte, vida/lectura, vida/escritura, espacio 1/espacio 2 , y el ser/el otro.

"Creación", el microcuento que abre el libro, es una especie de ars poetica, en la que el autor, como el pequeño Dios de Huidobro, presenta a un personaje al cual ordena crear y luego destruir. No en vano, el exordio de Julio Cortázar sirve de pretexto, no sólo al primer microcuento sino también, al libro en su totalidad: “...escribir es eso, abrirles los postigos/y que entren...". Las puestas unen y separan dos espacios, dos realidades. Las puertas se abren a espacios desconocidos, misteriosos, al arte como salvación, pero 
también al arte como condena y muerte. Otro microcuento que sirve de programa a todo el libro es "Conjuros", en el que el autor exorciza sus demonios y fantasmas, amenazándolos con comerciantes y banqueros. Como agentes del capital, estos últimos representan la corrupción, la traición, y la deshumanización, entre otros males sociales.

Los microcuentos de Cabrera comparten los rasgos esbozados por Raúl Brasca en su artículo "Los mecanismos de la brevedad". Entre los más importantes, además de la brevedad, obviamente, se encuentran el uso de diálogos, el absurdo, la presencia de animales, la paradoja y la referencialidad. A través de las referencias culturales, se apela al conocimiento enciclopédico del lector y, por tanto, a la complicidad para decodificar y recodificar el sentido, además de que inscriben la cultura europea en la tradición latinoamericana. En estos microcuentos, se pueden hallar referencias a literatura, música, y pintura: Guillermo Tell, Julio Cortázar, Jorge Luis Borges, Juan Bosch y Francisco de Goya.

El microcuento, también conocido como minicuento o microrrelato, es una narración breve, cercana a la parábola bíblica, al haikú, a la aporía y al aforismo. Así lo atestigua Augusto Monterroso, autor del microcuento más corto, "El dinosaurio": ("Cuando despertó el dinosaurio todavía estaba alli’”) y del título más largo: "Tú dile a Sarabia que digo yo que la nombre y que la comisione aquí o en donde quiera, que después le explico". El microcuento resume, si se quiere, el legado de apotegmas, proverbios, adagios, axiomas, epitafios, anécdotas, epigramas, y máximas, es decir, toda una gama de microestructuras, muchas veces de origen paratextual.

Marta Artisent explica el auge de estas microhistorias de la manera siguiente: "[E]xpresiones de la urgencia de nuestros tiempos, nuestra prisa para terminar las cosas y nuestra necesidad de ir al grano, para poder así escuchar más y más historias" (20). Esta crítico atribuye, además, el resurgimiento de este género a una actitud poshumanista de la cultura global que abraza "formas virtuales de 
comunicación" (19). Otros críticos consideran la brevedad y fragmentación como uno de los rasgos característicos de la posmodernidad. Sin embargo, este subgénero literario es tan antiguo como la lengua española misma. En El conde Lucanor (1335) del infante Don Juan Manuel o en el Libro del buen amor (1343) del Arcipreste de Hita encontramos ya este tipo de estructura en la literatura española. Más recientemente, en Europa, formas minimalistas aparecen en la obra de Kafka, Calvino, Beckett y Cioram; y, en Latinoamérica, Jorge Luis Borges, Juan José Arreola, Virgilio Piñera, y el ya nombrado Augusto Monterroso.

Los microcuentos de Cabrera son síntomas sino de la posmodernidad, al menos del descalabro de la sociedad dominicana de las últimas décadas, caracterizada por la violencia, el crimen, la corrupción, el nepotismo y la injusticia social. Los personajes y narradores agonizan en fantasmagorías de muerte. Cabrera apuntala una sociedad donde la pulsión de muerte permea no sólo a los personajes sino también a los lectores que tienen que enfrentar la imposibilidad del principio de vida, del goce, del erotismo... Si los personajes son incapaces de asumir el erotismo en su lucha contra la muerte (Eros vs. Tánatos), la afánisis entonces es una forma de protegerse de la muerte (Lacan).

Los microcuentos "Creación", "El amante", "El escritor", "Cita", "Fantasma", "Idilio", entre otros, son "suspiros" de la muerte, como diría Walter Benjamin. En su clásico ensayo "El cuentista", Benjamín reflexiona sobre la muerte y su vinculación con el cuento: "Pero es ante nada en el moribundo que, no sólo el saber y la sabiduría del mundo adquieren una forma transmisible, sino su vida vivida, y ése es el material del que nacen las historias" (121). Túnel negro, suspiro, epitafio, relámpago en la sien son imágenes que expresan la brevedad, la concisión, y la intensidad del microcuento. En "El escritor", el protagonista no lograba conciliar el sueño, por lo que decide sentarse a escribir. Como Ginés de Pasamonte o "Paropilla" en ElQuijote, la extensión de la historia coincide con 
la vida del autor, por lo que su finalización significa la muerte: "Cayó entonces al suelo, muerto" (14). Vida y escritura indisolublemente unidas.

La muerte como final del microcuento es la misma que imposibilita el erotismo, principio de placer. En "Cita", cuando el protagonista se encuentra con la amante, esta última ya estaba muerta: "Cuando le tendió la mano y se la estrechó -sintió un profundo escalofrío- lo entendió todo a cabalidad" (16). El correlato de "El escritor" es obviamente "El lector". En este microcuento, el protagonista lee un libro infinito, lo cual implica que la lectura sólo terminará con su muerte. De ahí que la vida dependa, en ambos casos, de la escritura y la lectura.

El absurdo y la fantasmagoría bordean la muerte. En "Años perdidos", al principio, los dos personajes tienen la misma edad, pero al final, el narrador dice que la edad de Ana sobrepasa la suya, porque sus años se han quedado rezagados. En éste y otros microcuentos, la lectura denotativa de una connotación o sistema segundo produce una ruptura (isotópica) del sentido que se abre a la poesía. Por esta razón, me gustaría denominar estos textos como microcuentemas, es decir, textos mínimos a horcajadas entre el microcuento y el poema.

En "Corazón”, un hombre tiene un "gran corazón”, que en nuestro código cultural puede interpretarse como bueno o generoso. Sin embargo, el hombre muere porque el corazón cada vez más agrandado le ha roto el pecho: "El corazón se me había salido del pecho en el que ya no cabía y ocupaba por completo la totalidad de la pieza" (6). Asimismo, "Los ojos del amo" remite al refrán "el ojo del amo engorda al caballo". El caballo, como protagonistadeudor de la fábula (En otros textos de este libro aparecen animales) es quien interpreta el refrán literalmente y le arranca los dos ojos al amo y se los come. 
Conjuros y otros microcuentos de Carlos Enrique Cabrera continúa la tradición del microcuento en Latinoamérica que, si bien no surge durante el boom, se enriquece con autores como Borges, Cortázar, Piñera y Arreola. Cabrera conjura una larga vida en estos textos breves (Ars longa. Vita brevis). Logra resemantizar los temas clásicos de la literatura latinoamericana contemporánea en un tomito de pulcros microrrelatos. Con la paciencia de un orfebre, Cabrera se posiciona con este libro como uno de los mejores escritores de la ficción mínima en la República Dominicana. 


\section{Referencias bibliográficas}

Altisent, M. E. Spanish Shorter-than-Short Fiction: Subverting Tradition. Hispanic Research Journal 4, 19-39.

Benjamin, W. (1991). Para una crítica de la violencia. Madrid: Taurus.

Brasca, R. Los mecanismos de la brevedad: Constantes y tendencias en el microcuento. Recuperado de http://cuentoenred.xoc.uam.mx/

Cabrera, C. E. (2013). Conjuros y otros microcuentos. Santo Domingo: Instituto Tecnológico de Santo Domingo.

Larrea, M. I. (2004). Estrategias lectoras en el microcuento. Estudios filológicos 39, 179-190.

Yepes, E. (1996). El microcuento hispanoamericano ante el próximo milenio. Revista Interamericana de bibliografía 46(4), 95-107. 